\title{
SISTEM PERAMALAN PENJUALAN PRODUK USAHA KECIL MENENGAH BERDASARKAN POLA DATA RIWAYAT PENJUALAN
}

\author{
${ }^{[1]}$ Abdi Pandu Kusuma, ${ }^{[2]}$ Indyah Hartami Santi, dan ${ }^{[3]}$ Dennys Setiawan

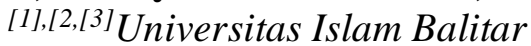

\begin{abstract}
Abstrak: Peramalan merupakan bagian dari sistem informasi manajemen yang dapat membantu pemilik perusahaan dalam pengambilan keputusan. Peramalan dapat berfungsi untuk memperkirakan penjualan dan penggunaan produk sehingga produkproduk itu dapat dibuat dalam kuantitas yang tepat. Proses peramalan memerlukan suatu metode yang tepat bergantung dari pola data yang ada dan informasi yang akan diramalkan serta tujuan yang hendak dicapai.Penelitian ini membahas tentang penerapan metode peramalan yang tepat pada suatu perusahaan sesuai dengan pola data yang ada. Metode peramalan yang digunakan adalah metode Trend Projection dan Double Exponential Smoothing. Metode peramalan Trend Projection lebih akurat apabila pola data yang ada pada perusahaan adalah pola data horizontal, sedangkan metode peramalan Double Exponential Smoothing akan lebih akurat apabila pola data yang ada pada perusahaan adalah pola data musiman.Data yang digunakan dalam penelitian ini merupakan data penjualan produk UD Omah Jenang Kelapa Sari dari bulan Januari tahun 2013 sampai dengan bulan Juli tahun 2017. Berdasarkan hasil analisis dan pengujian sistem, sistem ini dapat membantu pemilik perusahaan dalam meramalkan penjualan produk pada periode bulan berikutnya sehingga dapat digunakan sebagai pendukung keputusan dalam merencanakan produksi setiap bulannya.
\end{abstract}

Kata Kunci: Double Exponential Smoothing, Peramalan, Trend Projection

\section{Pendahuluan}

Perkembangan teknologi pada zaman ini berkembang dengan sangat cepat sejalan dengan besarnya kebutuhan terhadap informasi. Perkembangan teknologi sangatlah bermanfaat dalam menyelesaikan masalah pada suatu perusahaan. Masalah yang penting bagi sebuah perusahaan khususnya Usaha Kecil Menengah (UKM) salah satunya adalah masalah persediaan barang, terutama jika perusahaan tersebut bergerak dalam bidang distribusi barang. Tanpa adanya persediaan barang dagangan, perusahaan akan menghadapi resiko dimana pada suatu waktu tidak dapat memenuhi keinginan dari para pelanggannya. Tentu saja kenyataan ini dapat berakibat buruk bagi perusahaan, karena secara tidak langsung perusahaan menjadi kehilangan kesempatan untuk memperoleh keuntungan yang seharusnya didapatkan (Faisal, 2015). 
Salah satu UKM yang bergerak dalam bidang distribusi produk makanan tradisional adalah UD. Omah Jenang Kelapa Sari Blitar. Berdasarkan hasil dari wawancara terhadap pemilik UD. Omah Jenang Kelapa Sari Blitar, penjualan produk pada UKM ini setiap tahunnya mengalami peningkatan. Dengan adanya peningkatan transaksi penjualan tersebut, pemilik usaha harus merencanakan dan menyiapkan persediaan produk setiap bulannya. Namun dalam pendataan produk yang tersedia sering membutuhkan waktu yang lama. Hal ini berdampak pada proses pendistribusian dan juga tidak terkontrolnya penjualan produk karena perencanaan yang kurang matang.

Berdasarkan permasalahan tersebut, maka dalam penelitian ini dibuat suatu sistem informasi manajemen berbentuk program bantu yang dapat meramalkan jumlah penjualan produk berdasarkan pola data riwayat penjualan produk sebelumnya. Margianti dan Suryadi (2015) menjelaskan bahwa sistem informasi manajemen dapat digunakan sebagai alat bantu pendukung keputusan pada suatu perusahaan. Model peramalan yang digunakan untuk peramalan penjualan pada penelitian ini adalah Time Series dengan metode peramalan yang digunakan adalah metode Trend Projection dan DoubleExponential Smoothing (DES). Menurut Heizer dan Render (2008), tujuan metode Trend Projection adalah meminimalkan jumlah kuadrat kesalahan atau selisih dari persamaan regresi linier dengan masing-masing data sebenarnya. Dasar pemikiran dari metode Smoothing Eksponensial Linier Satu Parameter adalah sama dengan rata-rata bergerak linier karena ke dua nilai pemulusan tunggal dan ganda ketinggalan dari data sebenarnya (Brown, 1959).

Untuk pengujian keakuratan peramalan digunakan perhitungan Mean Squared Error (MSE), Mean Absolute Deviation (MAD) dan Mean Absolute Percent Error (MAPE). Keakuratan keseluruhan dari setiap model peramalan dapat dijelaskan dengan membandingkan nilai yang diramal dengan nilai aktual atau nilai yang sedang diamati. Kesalahan peramalan mengatakan seberapa baik kinerja suatu model dibandingkan dengan model itu sendiri dengan menggunakan data masa lalu (Heizer dan Render, 2008). Aplikasi dibuat berbasis web online sehingga dapat diakses di mana saja dan dapat digunakan sebagai salah satu media promosi. Hasil penelitian ini diharapkan dapat memberikan solusi bagi pemilik usaha kecil menengah dalam menentukan perencanaan dan juga membantu pemilik usaha dalam melakukan pengambilan keputusan untuk memanajemen persediaan produk yang sesuai dengan kebutuhan permintaan konsumen serta mengetahui keakuratan metode peramalan dalam meramalkan penjualan berdasarkan pola data riwayat penjualan yang ada. 


\section{Metode Penelitian}

\section{A. Tempat dan Waktu Penelitian}

Penelitian ini dilaksanakan di UD Omah Jenang Kelapa Sari Blitar yang berada di Jalan Masjid no.46 Desa Rejowinangun, Kecamatan Kademangan, Kabupaten Blitar. UD Omah Jenang Kelapa Sari Blitar merupakan salah satu UKM yang bergerak dalam bidang distribusi produk makanan tradisional seperti jenang, wajik dan madumangsa. Adapun waktu pelaksanaannya dimulai dari bulan Maret 2017 sampai dengan bulan Agustus 2017.

\section{B. Identifikasi Permasalahan}

Pada tahap ini dilakukan identifikasi terhadap permasalahan yang ada pada UD Omah Jenang Kelapa Sari Blitar. Berdasarkan hasil wawancara yang dilakukan peneliti terhadap pemilik UD Omah Jenang Kelapa Sari diketahui permasalahan pada UKM ini yaitu dalam mengolah data penjualan dan manajemen persediaan produk masih dilakukan secara manual. Setiap tahunnya, penjualan produk pada UKM ini mengalami peningkatan. Dengan adanya peningkatan transaksi penjualan tersebut, pemilik usaha harus merencanakan dan menyiapkan persediaan produk setiap bulan. Namun, dalam pendataan produk yang tersedia sering membutuhkan waktu yang lama. Hal ini berdampak pada proses pendistribusian dan juga tidak terkontrolnya penjualan produk karena perencanaan yang kurang matang. Dengan adanya permasalahan tersebut, maka diperlukan suatu metode yang dapat diaplikasikan dalam pengendalian persediaan produk yang sesuai dengan pola permintaan konsumen.

\section{Pengumpulan Data}

Pada tahap ini dilakukan pengumpulan informasi dan data yang diperlukan dalam penelitian. Data yang digunakan dalam penelitian ini adalah data penjualan produk pada UD Omah Jenang Kelapa Sari Blitar perbulan tahun 2013 sampai dengan tahun 2017. Teknik pengumpulan data yang dilakukan dalam penelitian ini sebagai berikut.

\section{Studi Literatur}

Berupa pengumpulan informasi dan mempelajari materi serta sumber-sumber data yang diperlukan untuk membangun sistem yang berhubungan dengan penelitian ini. Literatur-literatur diambil dari penelitian sebelumnya maupun dari beberapa buku, skripsi, dan jurnal-jurnal ilmiah, baik dalam negeri maupun luar negeri.

\section{Wawancara}

Kegiatan wawancara dilakukan secara langsung (face to face) antara peneliti dan pemilik UD Omah Jenang Kelapa Sari Blitar. Tujuan wawancara tersebut untuk memperoleh data yang dapat menjelaskan ataupun menjawab suatu permasalahan dalam penelitian.

\section{Observasi}

Observasi dilakukan secara langsung oleh peneliti di UD Omah Jenang Kelapa Sari Blitar. Peneliti mengumpulkan data dengan mencatat data penelitian 
berupa data penjualan produk UD Omah Jenang Kelapa Sari Blitar selama 5 tahun terakhir yaitu tahun 2013 sampai dengan tahun 2017.

\section{Analisis Data}

Pada tahap ini dilakukan analisis terhadap data yang diperoleh sebelumnya sesuai dengan metode peramalan yang telah ditentukan. Data yang digunakan dalam penganalisaan data adalah data penjualan produk pada UD Omah Jenang Kelapa Sari Blitar berupa jumlah produk yang terjual dengan satuan ukuran jumlah (pcs) dalam satu bulan selama 5 tahun terakhir yaitu dari tahun 2013 sampai dengan tahun 2017. Berdasarkan hasil observasi yang dilakukan diperoleh data dalam bentuk grafik garis berikut.

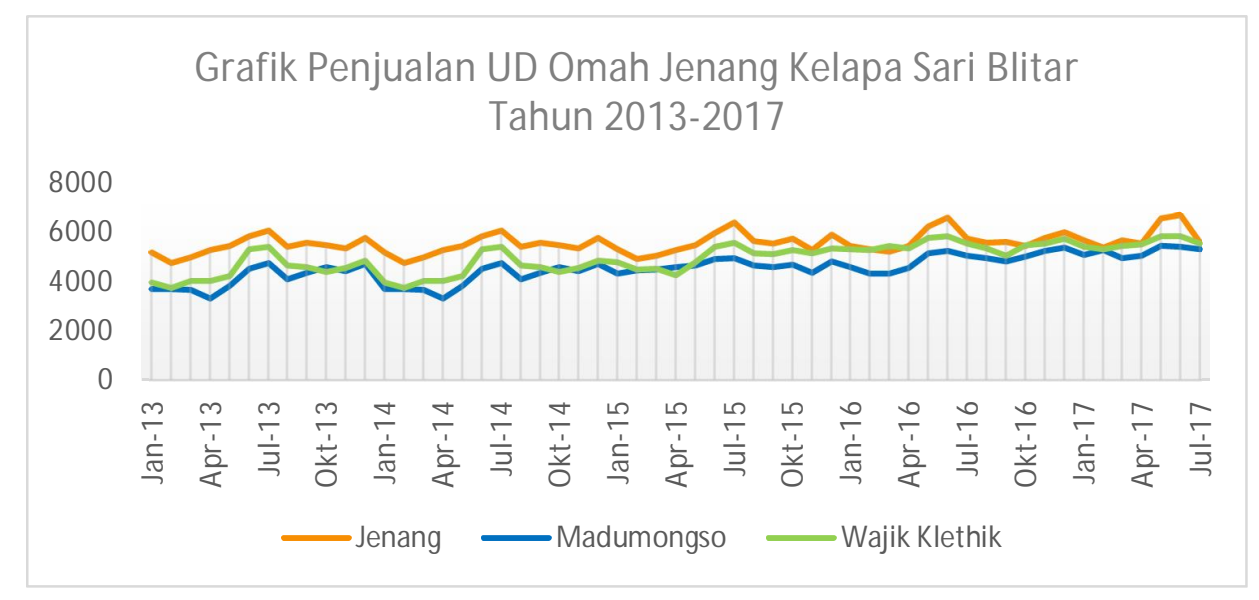

Gambar 1 Grafik Penjualan UD Omah Jenang Kelapa Sari Blitar tahun 2013-2017

Grafik 1 tersebut menunjukkan pola data penjualan produk pada UD Omah Jenang Kelapa Sari Blitar. Berdasarkan grafik 1 tersebut diketahui bahwa terdapat pola data musiman di mana setiap menjelang hari raya Idul Fitri dan menjelang hari raya Natal penjualan selalu meningkat.

\section{E. Perancangan Sistem}

Pada tahap ini dilakukan perancangan dan menentukan cara mengolah sistem informasi dari hasil analisis sistem sehingga dapat memenuhi kebutuhan dari pengguna, di antaranya perancangan alur sistem, data, dan aktivitas proses. Perancangan sistem berupa Data Flow Diagram (DFD), Flowchart, dan Entity Relationship Diagram (ERD). 


\section{Data Flow Diagram (DFD)}

DFD merupakan salah satu cara untuk memodelkan proses dalam analisis dan perancangan perangkat lunak. DFD perancangan sistem yang akan dibangun pada penelitian ini dapat ditunjukan pada gambar 2 berikut.

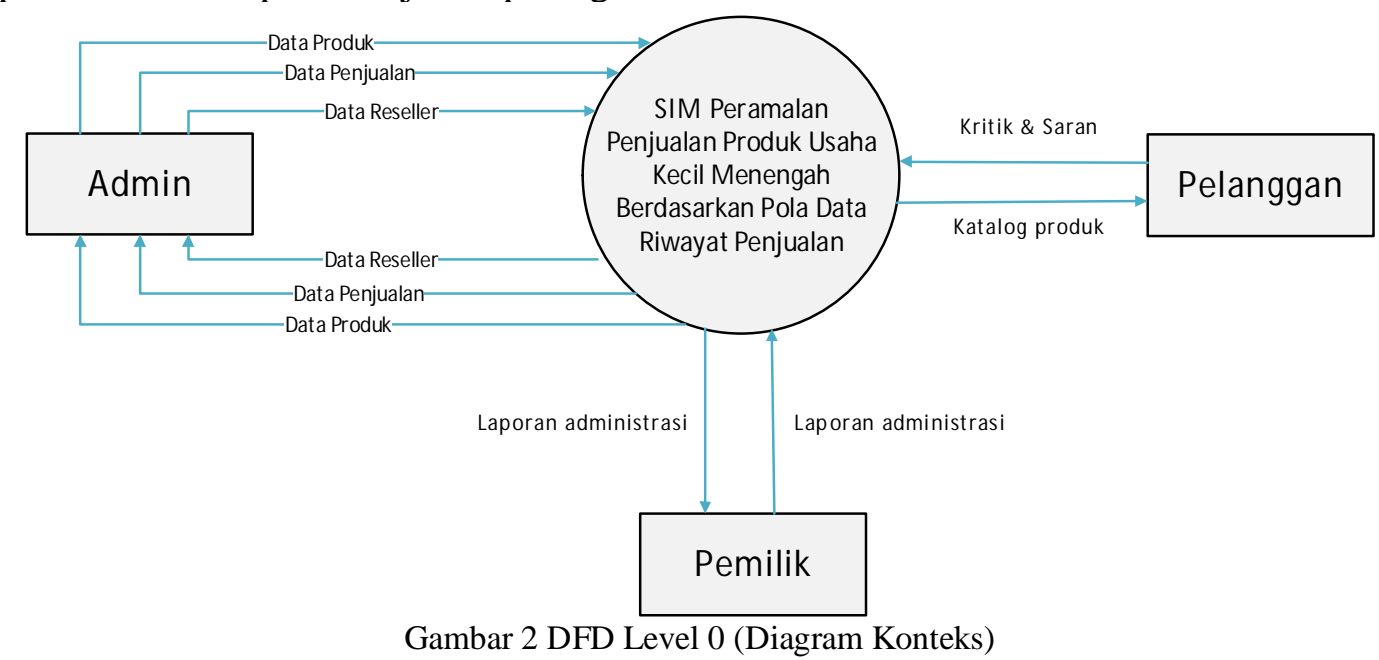

Penjelasan mengenai gambar 2 DFD Level 0 di atas sebagai berikut. Admin memberikan data produk, data penjualan dan data reseller pada sistem. Kemudian, sistem mengolah data produk, data penjualan, dan data reseller. Sistem menunjukkan katalog produk. Kemudian, Pelanggan memberikan kritik \& saran. Pemilik meminta laporan administrasi. Kemudian sistem memberikan laporan administrasi.

\section{Flowchart}

Flowchart merupakan gambar atau bagan yang memperlihatkan urutan dan hubungan antar proses beserta instruksinya. Flowchart pada penelitian ini terbagi menjadi 2 jenis yaitu Flowchart Sistem dan Flowchart Program. Flowchart Sistem merupakan bagan yang menunjukkan alur kerja atau apa yang sedang dikerjakan di dalam sistem secara keseluruhan dan menjelaskan urutan dari prosedur-prosedur yang ada di dalam sistem. Flowchart Sistem dalam penelitian ini ditunjukkan pada gambar 3. 


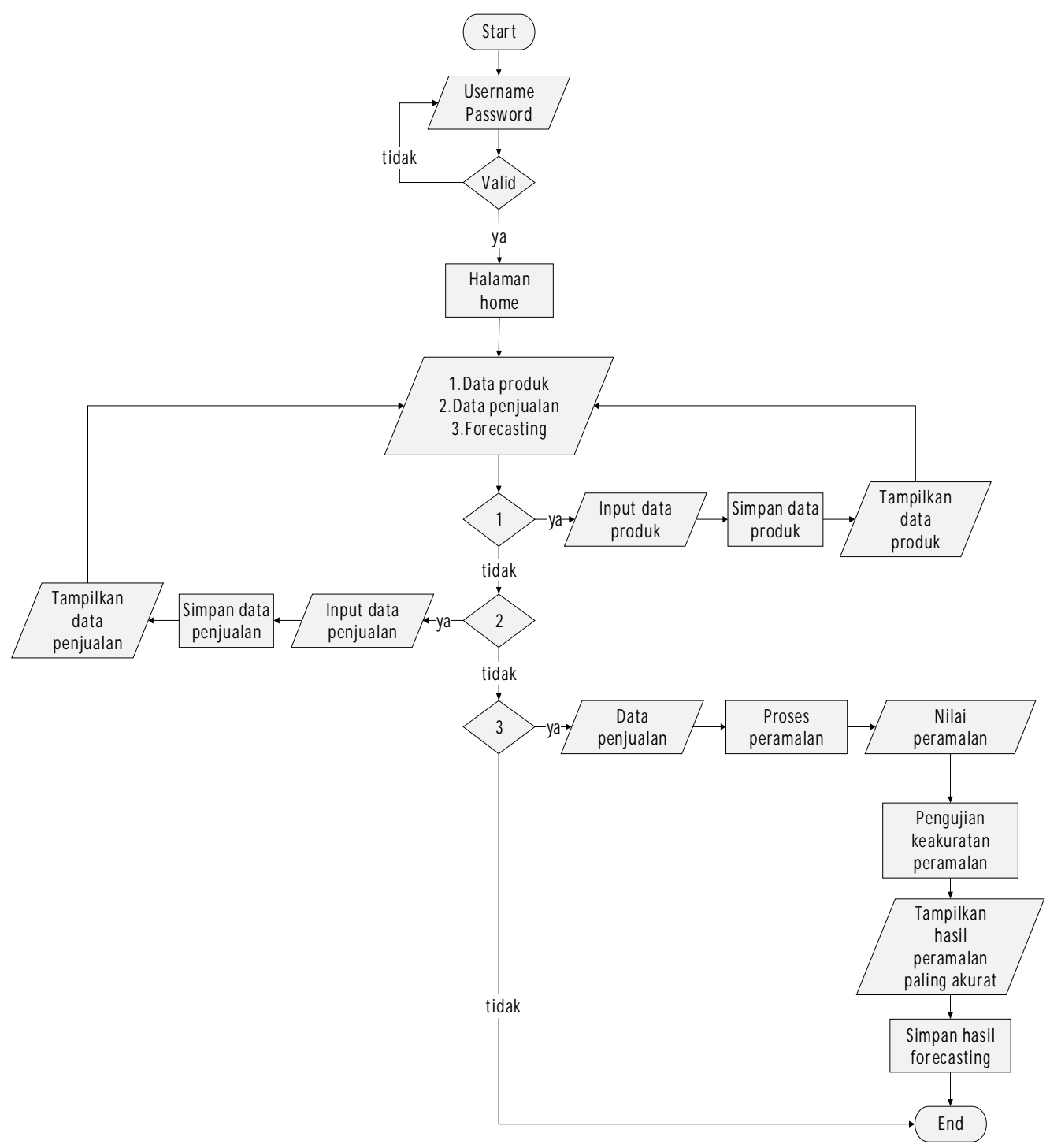

Gambar 3 Flowchart Sistem

Penjelasan yang berkaitan dengan flowchart sistem tersebut sebagai berikut. Sistem dimulai dari start, kemudian user login dengan memasukkan username dan password. Jika username dan password valid maka akan tampil halaman home. Jika tidak valid maka kembali ke panel login. Pada pilihan menu Data produk, user akan diarahkan ke halaman Data produk kemudian user dapat menginputkan serta mengelola data produk dan menyimpannya di database. Pada pillihan menu Data penjualan, user akan diarahkan ke halaman Data penjualan kemudian user dapat menginputkan serta mengelola data penjualan dan menyimpannya di database. Pada menu Forecasting, otomatis data produk dan data penjualan memasuki proses 
peramalan metode Trend dan DES yang kemudian menghasilkan nilai peramalan. Nilai peramalanotomatis akan dihitung tingkat keakuratannya menggunakan perhitungan $M A D, M S E$ dan $M A P E$. Nilai peramalanyang paling akurat darisalah satu metode kemudian ditampilkan.

Flowchart program merupakan bagan yang menjelaskan secara rinci langkahlangkah dari proses program. Bagan alir program dibuat dari derivikasi flowchart sistem. Flowchart program pada penelitian ini ditunjukkan pada gambar 4.

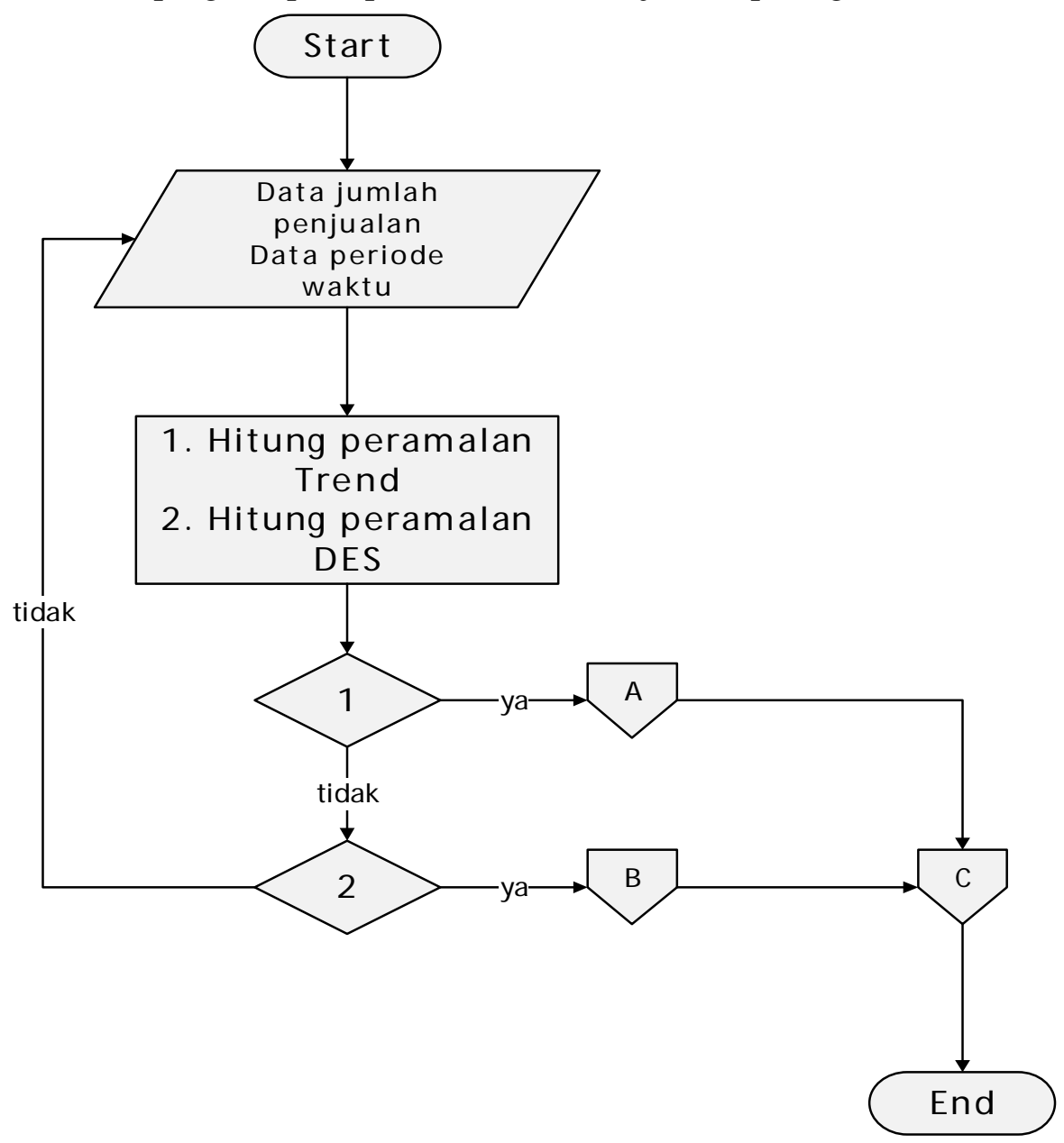

Gambar 4 Flowchart Program

Penjelasan yang berkaitan dengan flowchart program tersebut sebagai berikut. Flowchart program dimulai dari Start, kemudian sistem input data jumlah penjualan dan data periode waktu dilanjutkan pada proses perhitungan peramalan Trend dan $D E S$. Proses pertama, hitung nilai peramalan metode Trend dengan data menuju ke sub flowchart A yaitu proses perhitungan metode peramalan Trend. Sub flowchart A dapat dilihat pada gambar 5. Proses kedua, hitung nilai peramalan metode $D E S$ 
dengan data menuju ke sub flowchart B yaitu proses perhitungan metode DES. Sub flowchart B dapat dilihat pada gambar 6. Sub flowchart C merupakan lanjutan dari sub flowchart A dan B yaitu proses membandingkan nilai akurasi peramalan Trend dan DES. Sub flowchart C dapat dilihat pada gambar 7.Sub flowchart program perhitungan metode Trend Projection merupakan sub flowchart A lanjutan dari flowchart program pada gambar 4. Sub flowchart A dapat dilihat pada gambar 5.

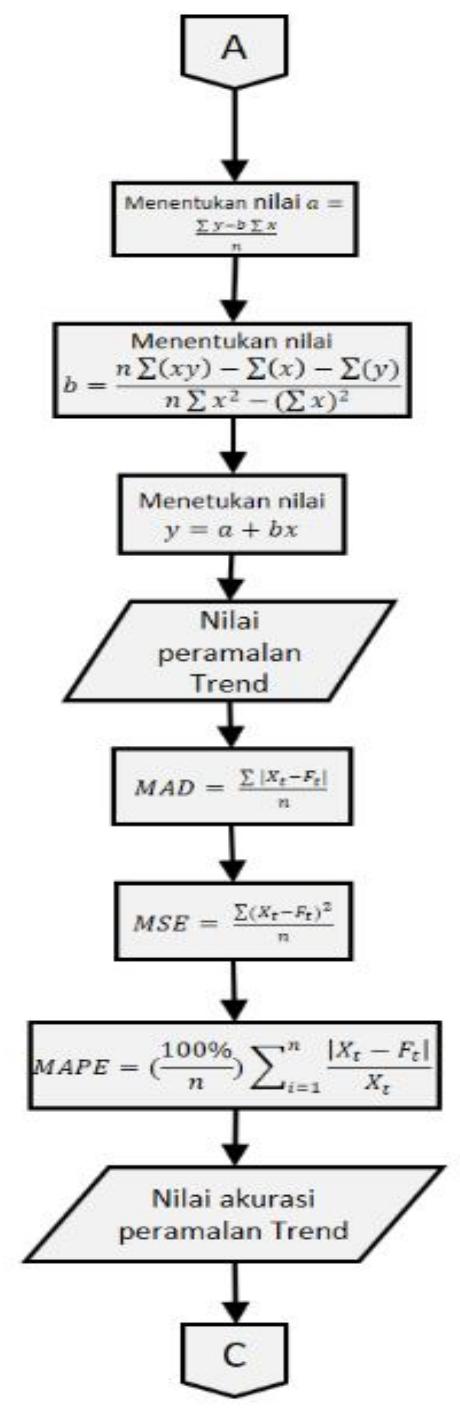

Gambar 5 SubFlowchart Program Perhitungan Metode Trend Projection

Penjelasan yang berkaitan dengan flowchart program tersebut sebagai berikut. Proses dimulai dari menentukan nilai $a$ kemudian dilanjutkan proses menentukan nilai $b$ lalu dilanjutkan menentukan nilai $y$ sehingga didapatkan nilai peramalan Trend. Selanjutnya, secara otomatis nilai peramalan Trend dihitung nilai 
keakuratannya dengan perhitungan $M A D, M S E$ dan MAPE sehingga didapat nilai akurasi peramalan Trend. Nilai akurasi peramalan Trend kemudian menuju ke sub flowchart $\mathrm{C}$ yang ditunjukkan pada gambar 7 .

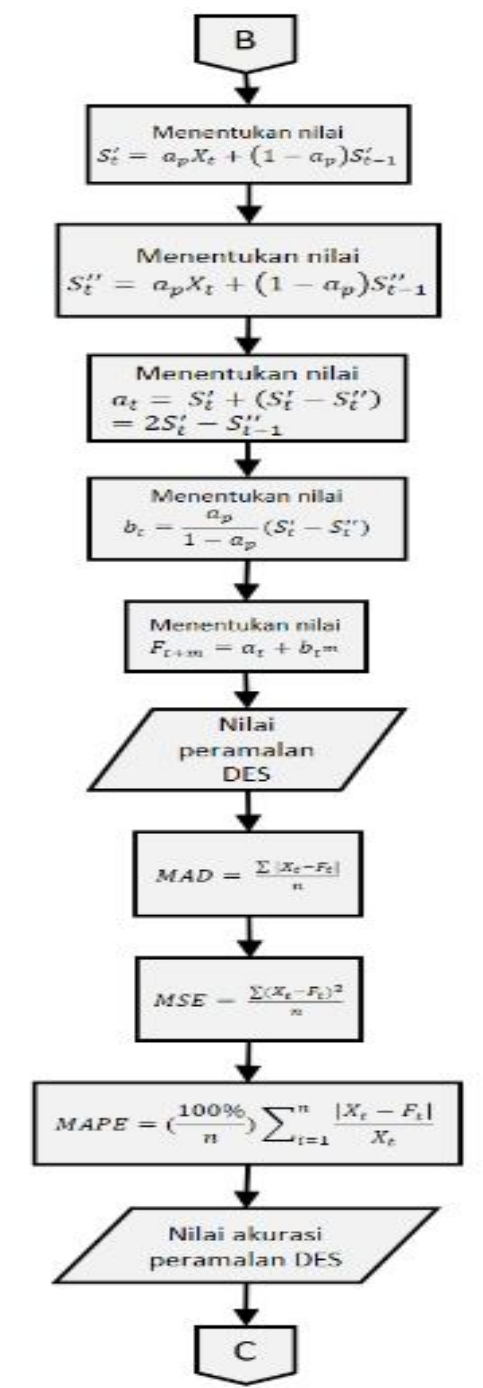

Gambar 6 SubFlowchart Program Perhitungan Metode Double Exponential Smoothing (DES)

Penjelasan yang berkaitan dengan flowchart program tersebut sebagai berikut. Sub flowchart program perhitungan metode Double Exponential Smoothing (DES) merupakan sub flowchart B lanjutan dari flowchart program pada gambar 4. Proses dimulai dari menentukan nilai $S^{\prime}{ }_{t}$ kemudian dilanjutkan menentukan nilai $S{ }^{\prime}{ }_{t}$. Setelah itu, proses dilanjutkan dengan menentukan nilai $a_{t}$. Kemudian, proses dilanjutkan dengan menentukan nilai $b_{t}$ untuk menentukan nilai $F_{t+m}$ sehingga didapatkan nilai peramalan DES. Nilai peramalan DES kemudian otomatis dihitung nilai 
keakuratannya dengan perhitungan $M A D, M S E$ dan $M A P E$ sehingga didapat nilai akurasi peramalan $D E S$. Nilai akurasi peramalan DES kemudian menuju ke sub flowchart $\mathrm{C}$ yang ditunjukkan pada gambar 7 .

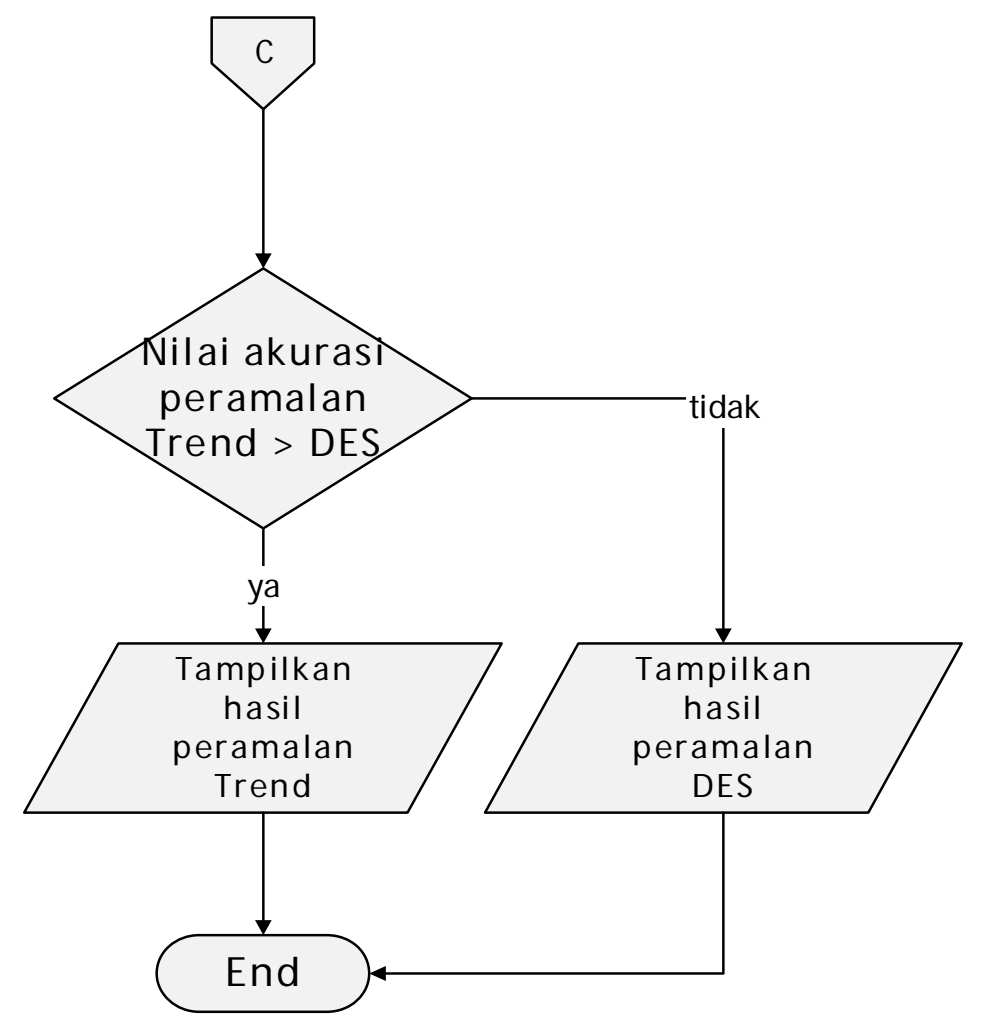

Gambar 7 SubFlowchart Program Proses Membandingkan Nilai Akurasi Peramalan Trend

$$
\text { dan DES }
$$

Penjelasan yang berkaitan dengan flowchart program tersebut sebagai berikut. Sub flowchart program Proses membandingkan nilai akurasi peramalan Trend dan DES merupakan sub flowchart C lanjutan dari flowchart program pada gambar 4, Sub flowchart A pada gambar 5 dan sub flowchart B pada gambar 6. Proses dimulai dari membandingkan nilai akurasi peramalan Trend dan DES. Jika nilai akurasi peramalan Trend lebih besar dari nilai akurasi peramalan DES, maka sistem akan menampilkan hasil peramalan Trend. Jika tidak, maka sistem akan menampilkan hasil peramalan DES. 


\section{Entity Relationship Diagram (ERD)}

ERD merupakan suatu model untuk menjelaskan hubungan antar data dalam basis data yang mempunyai hubungan antar relasi. ERD pada penelitian ini ditunjukkan pada gambar 8 berikut.

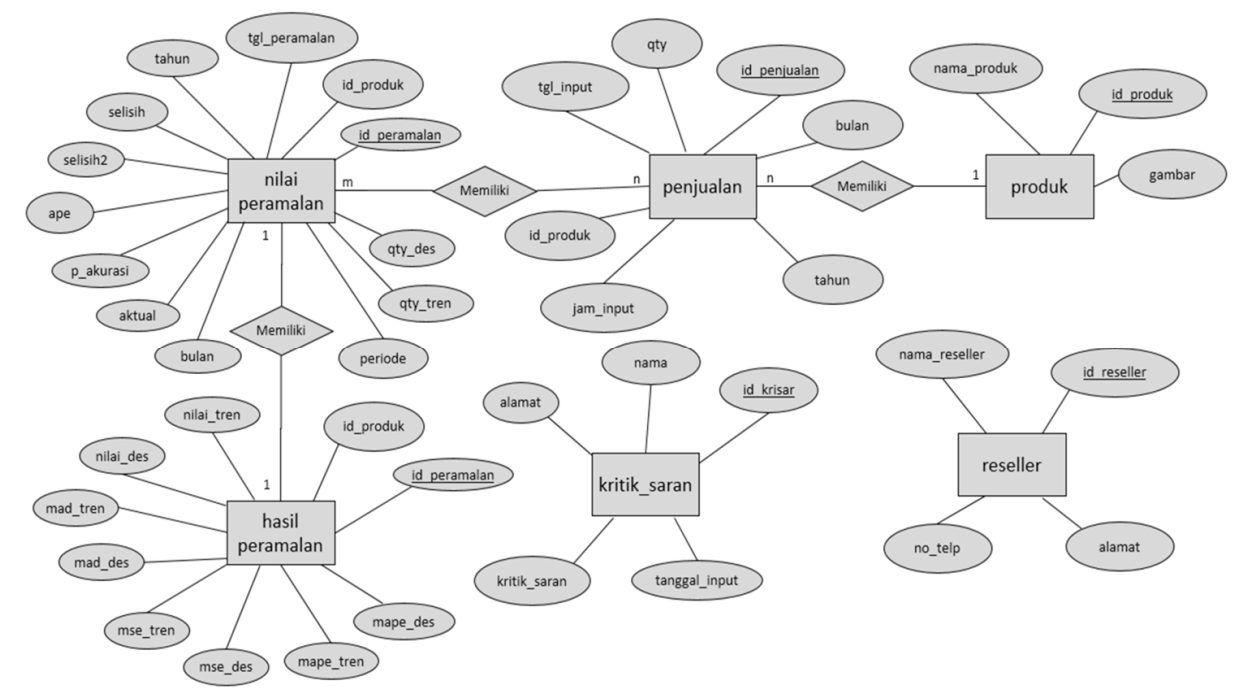

Gambar 8 Entity Relationship Diagram

Relasi antar tabel pada gambar 8 dapat diuraikan sebagai berikut.

1. Tabel produk terhubung dengan tabel penjualan, one to many

2. Tabel penjualan terhubung dengan tabel nilai peramalan, many to many

3. Tabel nilai peramalan terhubung dengan tabel hasil peramalan, one to one

\section{F. Analisis Kebutuhan Sistem}

Spesifikasi minimal kebutuhan komputer atau laptop yang dapat digunakan dalam implementasi sistem sebagai berikut.

1. Kebutuhan Perangkat Keras (Hardware)
(a) Prosesor Pentium V
(b) Memori/RAM 1 GB
(c) HDD $100 \mathrm{~GB}$

2. Kebutuhan Perangkat Lunak (Software)

(a) Sistem Operasi Windows 7, 8, 8.1, dan 10

(b) XAMPP tools yang terdiri dari apache sebagai WEB server penampil database dan MySQL sebagai database-nya

(c) Java jre8 dan jdk1.8 sebagai software pendukung sistem

(d) Web Browser Mozilla Firefox 


\section{HaSil dan PeMbahasan}

\section{A. Implementasi Sistem}

Pada tahap ini, dilakukan implementasi terhadap program untuk menghasilkan sistem yang sesuai dengan keinginan dan rancangan dan siap untuk dioperasikan pada kondisi yang sebenarnya. Adapun tampilan setiap halaman aplikasi sebagai berikut.

\section{Tampilan Halaman Login Admin}

Halaman login admin merupakan halaman form login untuk admin/user. Admin/user harusmenginputkan username dan password yang valid untuk masuk ke dalam sistem. Tampilan halaman login admin dapat dilihat pada gambar 9.

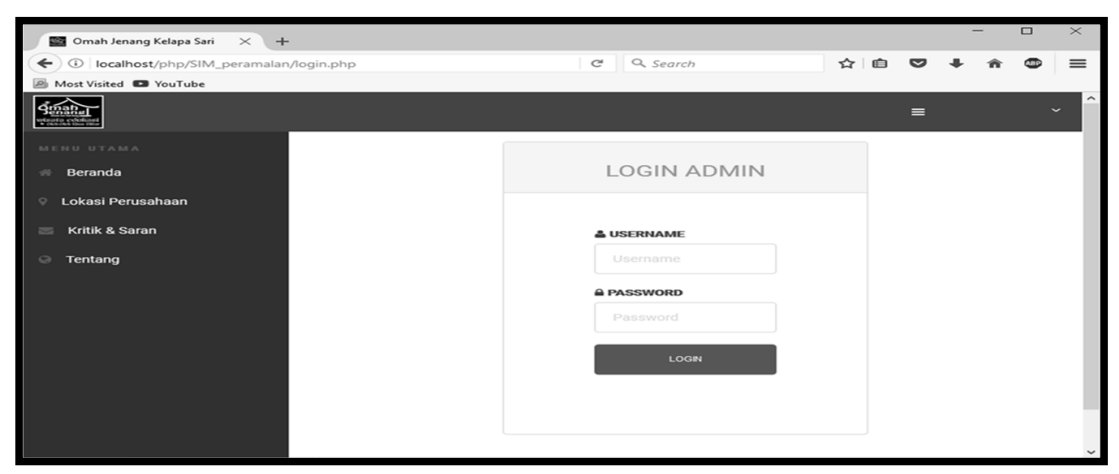

Gambar 9 Tampilan Halaman Login Admin

\section{Tampilan Halaman Forecasting}

Halaman forecasting merupakan halaman metode peramalan yang dikelola oleh admin. Admin dapat melihat peramalan penjualan setiap produk pada bulan berikutnya. Tampilan halaman forecasting dapat dilihat pada gambar 10.

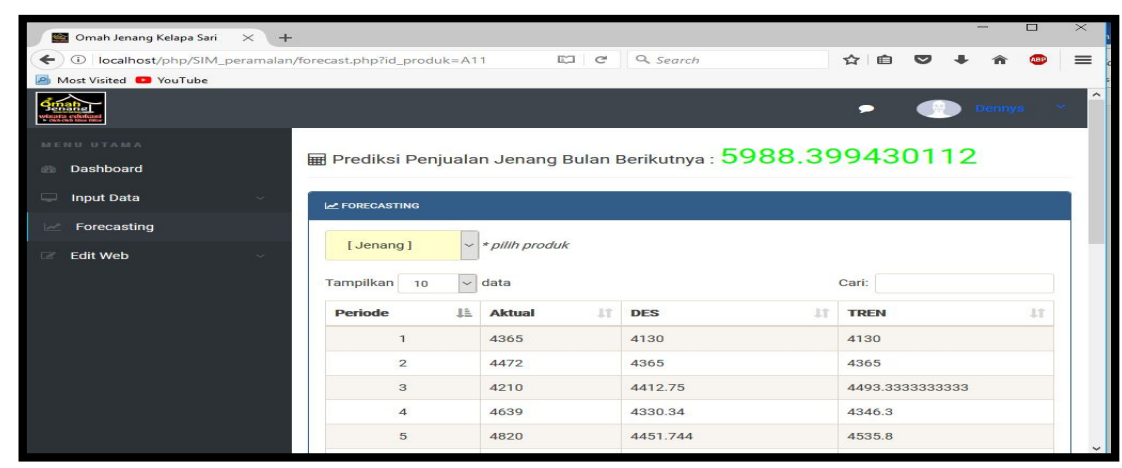

Gambar 10 Tampilan Halaman Forecasting

\section{B. Pengujian Sistem}

Antivirus: Jurnal IImiah dan Teknik Informatika, November 2017, Vol.11, No. 2 
Pengujian sistem dalam penelitian ini dilakukan menggunakan metode Black Box. Metode Black Box dipilih karena memiliki keunggulan dalam menentukan keberhasilan komponen hasil rancangan sistem. Selain itu, metode Black Box juga dapat digunakan untuk memastikan bahwa sistem dapat berfungsi sesuai dengan tujuan untuk setiap elemen yang terdapat dalam sistem. Prosedur pengujian dilakukan sesuai dengan fungsi masing-masing butir pengujian pada elemen yang diuji. Jika output yang dihasilkan sudah sesuai dengan tujuan berdasarkan input yang dimasukkan, maka dapat dikatakan berhasil.

\section{Pengujian Perhitungan Metode}

Pengujian perhitungan metode merupakan tahap pengujian pada metode yang digunakan dalam penelitian ini. Dari hasil pengujian perhitungan metode dapat dilihat kesesuaian perhitungan secara manual dengan perhitungan menggunakan aplikasi. Pengujian perhitungan metode menggunakan metode Trend Projection dan Double Exponential Smoothing (DES). Data yang digunakan dalam pengujian perhitungan metode yaitu data penjualan jenang mulai dari bulan Januari tahun 2013 sampai Juli tahun 2017.Pengujian perhitungan metode peramalan pada penelitian ini yaitu peramalan pada periode ke-55. Data hasil perhitungan manual pada penelitian ini disajikan dalam bentuk tabel.

\section{Perhitungan Metode Trend Projection}

Langkah penyelesaian perhitungan peramalan penjualan jenang pada periode ke 55 menggunakan metode Trend Projection adalah sebagai berikut.

1. Menghitung nilai $\sum X=1540$

2. Menghitung nilai $\sum X^{2}=53955$

3. Menghitung nilai $\left(\sum X\right)^{2}=2371600$

4. Menghitung nilai $\sum Y=300053$

5. Menghitung nilai $\sum X Y=8692176$

6. Menghitung nilai $b$

$$
\begin{aligned}
& b=\frac{n\left(\sum X Y\right)-\left(\sum X * \sum Y\right)}{n\left(\sum X^{2}\right)-\left(\sum X\right)^{2}} \\
& =((55 * 8692176)-(1540 * 300053)) /\left(\left(55^{*} 56980\right)-2371600\right) \\
& =(478069680-462081620) /(3133900-2371600) \\
& =15988060 / 762300 \\
& =20,9734488
\end{aligned}
$$

7. Menghitung nilai $a$

$$
\begin{aligned}
& a=\frac{\left(\sum Y\right)}{n}-b\left(\frac{\sum X}{n}\right) \\
& =(300053 / 55)-20,9734488 *(1540 / 55) \\
& =5455,50909-587256566 \\
& =4868,252525
\end{aligned}
$$


8. Menghitung nilai peramalan $(Y)$

$$
\begin{aligned}
& Y=a+b x \\
& =4868,252525+20,9734488 * 55 \\
& =6021.7922077922
\end{aligned}
$$

Hasil perhitungan dengan menggunakan metode Trend Projection menunjukkan bahwa peramalan penjualan produk jenang pada periode ke-55 atau bulan Agustus tahun 2017 sebanyak 6021.7922077922. Data hasil perhitungan metode Trend Projection dapat disajikan dalam bentuk tabel. Variabel $\mathrm{n}$ adalah jumlah data, $Y$ adalah nilai penjualan aktual, $X$ adalah periode waktu, $X^{2}$ adalah hasil pangkat nilai $X, X Y$ adalah hasil perkalian nilai $X$ dikali $Y$, y adalah nilai peramalan selanjutnya. $a$ dan $b$ adalah koefisien regresi. Adapun data hasil perhitungan peramalan penjualan jenang metode TrendProjection dapat dilihat pada tabel 1 .

TABEL 1

Data Hasil Perhitungan Peramalan Penjualan Jenang Metode Trend Projection

\begin{tabular}{lrrrrrlll}
\hline $\boldsymbol{n}$ & $\boldsymbol{Y}$ & $\boldsymbol{X}$ & \multicolumn{1}{c}{$\boldsymbol{X}^{2}$} & \multicolumn{1}{c}{$\boldsymbol{X} \boldsymbol{M}$} & \multicolumn{1}{c}{$\boldsymbol{a}$} & \multicolumn{1}{c}{$\boldsymbol{b}$} & \multicolumn{1}{c}{$\boldsymbol{y}$} \\
\hline 1 & 4130 & 0 & 0 & 0 & 4130 & 0 & 0 \\
2 & 4365 & 1 & 1 & 4365 & 3895 & 235 & 4130 \\
3 & 4472 & 2 & 4 & 8944 & 3980.33333333333 & 171 & 4365 \\
4 & 4210 & 3 & 9 & 12630 & 4207.5 & 34.7 & 4493.3333333333 \\
5 & 4639 & 4 & 16 & 18556 & 4104.3 & 86.3 & 4346.3 \\
6 & 4820 & 5 & 25 & 24100 & 4038.3333333333 & 114.57142857143 & 4535.8 \\
7 & 5655 & 6 & 36 & 33930 & 3805.5714285714 & 01.85714285714 & 4725.7619047619 \\
8 & 5903 & 7 & 49 & 41321 & 3684.9285714286 & 242.07142857143 & 5218.5714285714 \\
9 & 5050 & 8 & 64 & 40400 & 3865.722222222 & 187.83333333333 & 5621.5 \\
10 & 5251 & 9 & 81 & 47259 & 3964.3333333333 & 160.93939393939 & 5556.2222222222 \\
11 & 5309 & 10 & 100 & 53090 & 4041.7272727273 & 141.59090909091 & 5573.7272727273 \\
12 & 5545 & 11 & 121 & 60995 & 4074.3636363636 & 134.05944055944 & 5599.2272727273 \\
13 & 5170 & 12 & 144 & 62040 & 4173.9230769231 & 112.72527472527 & 5683.0769230769 \\
15 & 4985 & 14 & 196 & 69790 & 4396.6285714286 & 69.171428571429 & 5493.3714285714 \\
16 & 5268 & 15 & 225 & 79020 & 4426.05 & 63.979411764706 & 5434.2 \\
17 & 5438 & 16 & 256 & 87008 & 4434.9558823529 & 62.495098039216 & 5449.7205882353 \\
18 & 5820 & 17 & 289 & 98940 & 4406.0522875817 & 67.058823529412 & 5497.3725490196 \\
19 & 6055 & 18 & 324 & 108990 & 4366.5964912281 & 72.977192982456 & 5613.111111111 \\
21 & 5559 & 20 & 400 & 111180 & 4433.1619047619 & 63.625974025974 & 5747.7428571429 \\
22 & 5456 & 21 & 441 & 114576 & 4467.4285714286 & 59.156408808583 & 5769.3073593074 \\
23 & 5349 & 22 & 484 & 117678 & 4509.0830039526 & 53.949604743083 & 5768.8695652174 \\
24 & 5760 & 23 & 529 & 132480 & 4512.7391304348 & 53.510869565217 & 5749.9239130435 \\
26 & 4916 & 25 & 625 & 122900 & 4624.6523076923 & 40.894700854701 & 5770.5261538462 \\
27 & 5045 & 26 & 676 & 131170 & 4675.3048433048 & 35.467643467643 & 5687.9145299145 \\
28 & 5258 & 27 & 729 & 141966 & 4704.619047619 & 32.435139573071 & 5632.9312169312 \\
29 & 5468 & 28 & 784 & 153104 & 4716.842364532 & 31.212807881773 & 5612.802955665 \\
\hline & & & & & & & &
\end{tabular}

TABEL 1 LANJUTAN 
Data Hasil Perhitungan Peramalan Penjualan Jenang Metode Trend Projection

\begin{tabular}{ccccclll}
\hline $\boldsymbol{n}$ & $\boldsymbol{Y}$ & $\boldsymbol{X}$ & $\boldsymbol{X}^{2}$ & $\boldsymbol{X} \boldsymbol{Y}$ & \multicolumn{1}{c}{$\boldsymbol{a}$} & \multicolumn{1}{c}{$\boldsymbol{b}$} & $\boldsymbol{y}$ \\
\hline 30 & 5970 & 29 & 841 & 173130 & 4695.724137931 & 33.256507230256 & 5622.0137931034 \\
31 & 6385 & 30 & 900 & 191550 & 4653.2516129032 & 37.238306451613 & 5693.4193548387 \\
32 & 5624 & 31 & 961 & 174344 & 4667.0564516129 & 35.98332111437 & 5807.6391129032 \\
33 & 5529 & 32 & 1024 & 176928 & 4686.7840909091 & 34.242647058824 & 5818.5227272727 \\
34 & 5736 & 33 & 1089 & 189288 & 4693.550802139 & 33.662643239114 & 5816.7914438503 \\
35 & 5269 & 34 & 1156 & 179146 & 4727.9932773109 & 30.79243697479 & 5838.0806722689 \\
36 & 5890 & 35 & 1225 & 206150 & 4725.0222222222 & 31.033333333333 & 5805.7285714286 \\
37 & 5442 & 36 & 1296 & 195912 & 4748.3333333333 & 29.19298245614 & 5842.2222222222 \\
38 & 5298 & 37 & 1369 & 196026 & 4777.7894736842 & 26.927125506073 & 5828.4736842105 \\
39 & 5193 & 38 & 1444 & 197334 & 4810.350877193 & 24.485020242915 & 5801.020242915 \\
40 & 5424 & 39 & 1521 & 211536 & 4828.6384615385 & 23.146904315197 & 5765.2666666667 \\
41 & 6243 & 40 & 1600 & 249720 & 4805.9390243902 & 24.768292682927 & 5754.5146341463 \\
42 & 6594 & 41 & 1681 & 270354 & 4770.3298490128 & 27.252653755773 & 5821.4390243902 \\
43 & 5732 & 42 & 1764 & 240744 & 4780.1063122924 & 26.586076713984 & 5914.9413067553 \\
44 & 5558 & 43 & 1849 & 238994 & 4797.9196617336 & 25.398520084567 & 5923.3076109937 \\
45 & 5613 & 44 & 1936 & 246972 & 4812.4909090909 & 24.448221343874 & 5915.4545454545 \\
46 & 5424 & 45 & 2025 & 244080 & 4834.8 & 23.024236817761 & 5912.6608695652 \\
47 & 5758 & 46 & 2116 & 264868 & 4841.5633672525 & 22.601526364477 & 5893.914893617 \\
48 & 5983 & 47 & 2209 & 281201 & 4839.2065602837 & 22.745820668693 & 5903.835106383 \\
49 & 5654 & 48 & 2304 & 271392 & 4851.4413265306 & 22.011734693878 & 5931.005952381 \\
50 & 5358 & 49 & 2401 & 262542 & 4875.2024489796 & 20.614021608643 & 5930.0163265306 \\
51 & 5675 & 50 & 2500 & 283750 & 4885.0658823529 & 20.044977375566 & 5905.9035294118 \\
52 & 5546 & 51 & 2601 & 282846 & 4899.7352941176 & 19.214633313412 & 5907.3597285068 \\
53 & 6543 & 52 & 2704 & 340236 & 4876.1545718433 & 20.524673439768 & 5898.8962264151 \\
54 & 6690 & 53 & 2809 & 354570 & 4850.0244584207 & 21.949952353726 & 5963.9622641509 \\
55 & 5556 & 54 & 2916 & 300024 & 4868.2525252525 & 20.973448773449 & 6035.3218855219 \\
\hline Peramalan penjualan periode ke-55 & & & 6021.7922077922 \\
\hline & & & & & & &
\end{tabular}

\section{Perhitungan Metode Double Exponential Smoothing (DES)}

Langkah penyelesaian perhitungan peramalan penjualan jenang pada periode ke-55 menggunakan metode Double Exponential Smoothing adalah sebagai berikut.

1. Menghitung nilai $a_{p}$

$$
a_{p}=1 / \mathrm{t}=1 / 55=0,01818 \sim 0,1
$$

2. Menghitung nilai $S_{t}$

$$
\begin{aligned}
& S_{t}^{\prime}=a_{p} X_{t}+\left(1-a_{p}\right) S_{t-1}^{\prime} \\
& =0,1 * 5556+(1-0,1) * 5816.3561174543 \\
& =555,6+0,9 * 5816.3561174543 \\
& =555,6+5234.72050570887 \\
& =5790.32050570887
\end{aligned}
$$

3. Menghitung nilai $S{ }_{t}$

$$
S_{t}^{\prime \prime}=a_{p} S_{t}^{\prime}+\left(1-a_{p}\right) S_{t-1}^{\prime \prime}
$$




$$
\begin{aligned}
& =0,1 * 5790.32050570887+(1-0,1) * 5592.2415813057 \\
& =579.032050570887+0,9 * 5592.2415813057 \\
& =579.032050570887+5033.01742317513 \\
& =5612.049473746017
\end{aligned}
$$

4. Menghitung nilai $a_{t}$

$$
\begin{aligned}
& a_{t}=S_{t}^{\prime}+\left(S_{t}^{\prime}-S_{t}^{\prime \prime}\right)=2 S_{t}^{\prime}-S_{t}^{\prime \prime} \\
& =5790.32050570887+(5790.32050570887-5612.049473746017) \\
& =2 * 5790.32050570887-5612.049473746017 \\
& =5968.591537671723
\end{aligned}
$$

5. Menghitung nilai $b_{t}$

$$
\begin{aligned}
& b_{t}=\frac{a_{p}}{1-a_{p}}\left(S_{t}^{\prime}-S_{t}^{\prime \prime}\right) \\
& =0.1 / 1-0.1 *(5790.32050570887-5612.049473746017) \\
& =0.1 / 0.9 *(178.271031962853) \\
& =0.111111111111111 * 178.271031962853 \\
& =19.807892440317
\end{aligned}
$$

6. Menghitung nilai peramalan $\left(F_{t}\right)$

$$
\begin{aligned}
& F_{t+m}=a_{t}+b_{t} m \\
& F t+1=5968.591537671723+(19.807892440317 * 1) \\
& =5968.591537671723+19.807892440317 \\
& =5988.39943011204
\end{aligned}
$$

Hasil perhitungan dengan menggunakan metode Double Exponential Smoothing menunjukkan peramalan penjualan produk jenang pada periode ke-55 atau bulan Agustus tahun 2017 sebanyak 5988.39943011204. Data hasil perhitungan metode Double Exponential Smoothing (DES) dapat disajikan dalam bentuk tabel berikut. Variabel $t$ adalah periode waktu, $x$ adalah nilai penjualan aktual, $S^{\prime}{ }_{t}$ adalah nilai pemulusan tunggal, $S$ " ${ }_{t}$ adalah nilai pemulusan ganda, $F_{t}$ adalah nilai peramalan selanjutnya. $a_{t}$ dan $b_{t}$ adalah konstanta pemulusan. Adapun data hasil perhitungan peramalan penjualan jenang metode Double Exponential Smoothing (DES) dapat dilihat pada tabel 2 . 
Data Hasil Perhitungan Peramalan Penjualan Jenang Metode Double Exponential SMOOTHING (DES)

\begin{tabular}{|c|c|c|c|c|c|c|}
\hline$t$ & $x$ & $S_{t}^{\prime}$ & $S^{\prime \prime}{ }_{t}$ & $a_{t}$ & $b_{t}$ & $F_{t}$ \\
\hline 0 & 4130 & 4130 & 4130 & 4130 & 0 & 0 \\
\hline 1 & 4365 & 4247.5 & 4188.75 & 4306.25 & 58.75 & 4130 \\
\hline 2 & 4472 & 4281.95 & 4190.39 & 4373.51 & 39.24 & 4365 \\
\hline 3 & 4210 & 4260.365 & 4211.3825 & 4309.3475 & 20.9925 & 4412.75 \\
\hline 4 & 4639 & 4312.44 & 4200.9968 & 4423.8832 & 27.8608 & 4330.34 \\
\hline 5 & 4820 & 4413.952 & 4243.58784 & 4584.31616 & 42.59104 & 4451.744 \\
\hline 6 & 5655 & 4427.976135 & 4191.916719 & 4664.035551 & 26.228824 & 4626.9072 \\
\hline 7 & 5903 & 4575.4785215 & 4230.27289925 & 4920.68414375 & 38.35618025 & 4690.264375 \\
\hline 8 & 5050 & 4622.93066935 & 4269.53867626 & 4976.32266244 & 39.26577701 & 4959.040324 \\
\hline 9 & 5251 & 4685.737602415 & 4311.1585688755 & 5060.3166359545 & 41.6198926155 & 5015.58843945 \\
\hline 10 & 5309 & 4748.0638421735 & 4354.8490962053 & 5141.2785881417 & 43.6905273298 & 5101.93652857 \\
\hline 11 & 5545 & 4827.7574579562 & 4402.1399323804 & 5253.3749835319 & 47.290836175085 & 5184.9691154715 \\
\hline 12 & 5170 & 4861.9817121605 & 4448.1241103584 & 5275.8393139627 & 45.984177978015 & 5300.665819707 \\
\hline 13 & 4746 & 4850.3835409445 & 4488.350053417 & 5212.417028472 & 40.225943058608 & 5321.8234919407 \\
\hline 14 & 4985 & 4863.84518685 & 4525.8995667603 & 5201.7908069398 & 37.549513343303 & 5252.6429715306 \\
\hline 15 & 5268 & 4904.260668165 & 4563.7356769008 & 5244.7856594293 & 37.836110140472 & 5239.3403202831 \\
\hline 16 & 5438 & 4957.6346013485 & 4603.1255693456 & 5312.1436333515 & 39.389892444774 & 5282.6217695698 \\
\hline 17 & 5820 & 5043.8711412137 & 4647.2001265324 & 5440.542155895 & 44.074557186812 & 5351.5335257963 \\
\hline 18 & 6055 & 5144.9840270923 & 4696.9785165884 & 5592.9895375963 & 49.778390055994 & 5484.6167130818 \\
\hline 19 & 5404 & 5170.8856243831 & 4744.3692273678 & 5597.4020213983 & 47.390710779471 & 5642.7679276522 \\
\hline 20 & 5559 & 5209.6970619448 & 4790.9020108255 & 5628.492113064 & 46.532783457693 & 5644.7927321778 \\
\hline 21 & 5456 & 5234.3273557503 & 4835.244545318 & 5633.4101661826 & 44.342534492476 & 5675.0248965217 \\
\hline 22 & 5349 & 5245.7946201753 & 4876.2995528037 & 5615.2896875468 & 41.055007485726 & 5677.7527006751 \\
\hline 23 & 5760 & 5297.2151581577 & 4918.3911133391 & 5676.0392029763 & 42.0915605354 & 5656.3446950325 \\
\hline 24 & 5320 & 5299.493642342 & 4956.5013662394 & 5642.4859184445 & 38.110252900283 & 5718.1307635117 \\
\hline 25 & 4916 & 5261.1442781078 & 4986.9656574263 & 5535.3228987893 & 30.464291186835 & 5680.5961713448 \\
\hline 26 & 5045 & 5239.529850297 & 5012.2220767133 & 5466.8376238807 & 25.256419287074 & 5565.7871899761 \\
\hline 27 & 5258 & 5241.3768652673 & 5035.1375555687 & 5447.6161749659 & 22.915478855397 & 5492.0940431677 \\
\hline 28 & 5468 & 5264.0391787406 & 5058.0277178859 & 5470.0506395952 & 22.890162317184 & 5470.5316538213 \\
\hline 29 & 5970 & 5334.6352608665 & 5085.688472184 & 5583.582049549 & 27.66075429806 & 5492.9408019124 \\
\hline 30 & 6385 & 5439.6717347799 & 5121.0867984436 & 5758.2566711162 & 35.398326259589 & 5611.2428038471 \\
\hline 31 & 5624 & 5458.1045613019 & 5154.7885747294 & 5761.4205478744 & 33.701776285831 & 5793.6549973757 \\
\hline 32 & 5529 & 5465.1941051717 & 5185.8291277736 & 5744.5590825697 & 31.040553044229 & 5795.1223241602 \\
\hline 33 & 5736 & 5492.2746946545 & 5216.4736844617 & 5768.0757048473 & 30.64455668809 & 5775.599635614 \\
\hline 34 & 5269 & 5469.9472251891 & 5241.8210385344 & 5698.0734118437 & 25.347354072735 & 5798.7202615354 \\
\hline 35 & 5890 & 5511.9525026702 & 5268.834184948 & 5755.0708203923 & 27.013146413571 & 5723.4207659164 \\
\hline 36 & 5442 & 5504.9572524031 & 5292.4464916935 & 5717.4680131128 & 23.612306745513 & 5782.0839668059 \\
\hline 37 & 5298 & 5484.2615271628 & 5311.6279952405 & 5656.8950590852 & 19.18150354693 & 5741.0803198583 \\
\hline 38 & 5193 & 5455.1353744465 & 5325.9787331611 & 5584.292015732 & 14.350737920609 & 5676.0765626321 \\
\hline 39 & 5424 & 5452.0218370019 & 5338.5830435451 & 5565.4606304586 & 12.604310384082 & 5598.6427536526 \\
\hline 40 & 6243 & 5531.1196533017 & 5357.8367045208 & 5704.4026020826 & 19.253660975655 & 5598.6427536526 \\
\hline 41 & 6594 & 5637.4076879715 & 5385.7938028659 & 5889.0215730772 & 27.957098345073 & 5578.0649408427 \\
\hline 42 & 5732 & 5646.8669191744 & 5411.9011144967 & 5881.832723852 & 26.10731163085 & 5723.6562630583 \\
\hline 43 & 5558 & 5637.9802272569 & 5434.5090257727 & 5841.4514287411 & 22.607911276021 & 5916.9786714223 \\
\hline 44 & 5613 & 5635.4822045312 & 5454.6063436486 & 5816.3580654139 & 20.09731787585 & 5907.9400354829 \\
\hline
\end{tabular}

TABEL 2 LANJUTAN 
Data Hasil Perhitungan Peramalan Penjualan Jenang Metode Double Exponential SMOOTHING (DES)

\begin{tabular}{cclllll}
\hline $\boldsymbol{t}$ & $\boldsymbol{x}$ & \multicolumn{1}{c}{$\boldsymbol{S}_{\boldsymbol{t}}^{\prime}$} & \multicolumn{1}{c}{$\boldsymbol{S}_{\boldsymbol{t}_{\boldsymbol{t}}}$} & \multicolumn{1}{c}{$\boldsymbol{a}_{\boldsymbol{t}}$} & \multicolumn{1}{c}{$\boldsymbol{b}_{\boldsymbol{t}}$} & \multicolumn{1}{c}{$\boldsymbol{F}_{\boldsymbol{t}}$} \\
\hline 45 & 5424 & 5614.3339840781 & 5470.5791076916 & 5758.0888604647 & 15.972764042952 & 5864.0593400172 \\
46 & 5758 & 5628.7005856703 & 5486.3912554894 & 5771.0099158512 & 15.812147797876 & 5774.0616245076 \\
47 & 5983 & 5664.1305271033 & 5504.1651826508 & 5824.0958715557 & 17.773927161385 & 5786.8220636491 \\
48 & 5654 & 5663.117474393 & 5520.060411825 & 5806.1745369609 & 15.895229174214 & 5841.8697987171 \\
49 & 5358 & 5632.6057269537 & 5531.3149433379 & 5733.8965105694 & 11.254531512863 & 5822.0697661351 \\
50 & 5675 & 5636.8451542583 & 5541.8679644299 & 5731.8223440867 & 10.55302109204 & 5745.1510420823 \\
51 & 5546 & 5627.7606388325 & 5550.4572318702 & 5705.0640457947 & 8.5892674402533 & 5742.3753651787 \\
52 & 6543 & 5719.2845749492 & 5567.3399661781 & 5871.2291837203 & 16.882734307903 & 5713.653313235 \\
53 & 6690 & 5816.3561174543 & 5592.2415813057 & 6040.4706536029 & 24.901615127621 & 5888.1119180283 \\
54 & 5556 & 5790.3205057089 & 5612.049473746 & 5968.5915376717 & 19.807892440316 & 6065.3722687305 \\
\hline \multicolumn{7}{l}{ Peramalan penjualan periode ke-55 } \\
\hline \multicolumn{7}{l}{}
\end{tabular}

\section{Perhitungan Kesalahan Peramalan Metode Trend Projection (Trend)}

Pengujian perhitungan kesalahan peramalan pada kasus ini untuk mengetahui tingkat akurasi peramalan Trend pada periode ke-55. Pada penelitian ini digunakan metode Mean Absolute Deviation (MAD), Mean Squared Error (MSE) dan Mean Absolute Percent Error (MAPE) untuk menghitung kesalahan peramalan (forecast error).

\section{a. MAD Trend}

Langkah menghitung kesalahan peramalan Trend periode ke-55 menggunakan perhitungan MAD yaitu sebagai berikut.

(1) Menghitung selisih antara nilai peramalan dengan data aktual tiap periode

$$
\left|A_{t}-F_{t}\right|
$$

(2) Menjumlahkan selisih antara nilai peramalan dengan data aktual tiap periode $\sum\left|A_{t}-F_{t}\right|$, diperoleh nilai 20877.242024848187

(3) Jumlah selisih dibagi dengan jumlah data

$$
M A D=\frac{\sum\left|A_{t}-F_{t}\right|}{n}=20877.242024848187 / 54=386.61559305274
$$

\section{b. MSE Trend}

Langkah menghitung kesalahan peramalan Trend periode ke-55 menggunakan perhitungan MSE yaitu sebagai berikut.

(1) Menghitung selisih antara hasil peramalan dengan data aktual tiap periode

$$
\left|A_{t}-F_{t}\right|
$$

(2) Mengkuadratkan selisih antara nilai peramalan dengan data aktual tiap periode $\left|\left(A_{t}-F_{t}\right)^{2}\right|$

(3) Menjumlahkan hasil kuadrat dari selisih antara nilai peramalan dengan data aktual tiap periode $\sum\left|\left(A_{t}-F_{t}\right)^{2}\right|$, diperoleh nilai 10848826.188980019

(4) Jumlah selisih kuadrat dibagi dengan jumlah data 


$$
M S E=\frac{\sum\left|\left(A_{t}-F_{t}\right)^{2}\right|}{n}=10848826.188980019 / 54=200904.18868482
$$

\section{c. MAPE Trend}

Langkah menghitung kesalahan peramalan Trend periode ke-55 menggunakan perhitungan MAPE yaitu sebagai berikut.

(1) Menghitung selisih antara hasil peramalan dengan data aktual tiap periode $\left|A_{t}-F_{t}\right|$

(2) Menghitung nilai APE tiap periode peramalan $\left(100-\left(\left(\left|A_{t}-F_{t}\right| / n\right) * 100\right)\right)$

(3) Menjumlahkan nilai APE seluruh periode peramalan $\left(\sum A P E\right)$, diperoleh nilai 382.5232363828348

(4) Menjumlahkan nilai APE seluruh periode peramalan dibagi jumlah data, dengan perhitungan $M A P E=\sum A P E / n=382.5232363828348 \quad / \quad 54=$ 7.0837636367192 .

\section{Perhitungan Kesalahan Peramalan Metode Double Exponential Smoothing (DES)}

Pengujian perhitungan kesalahan peramalan pada kasus ini untuk mengetahui tingkat akurasi peramalan DES pada periode ke-55. Pada penelitian ini digunakan metode Mean Absolute Deviation (MAD), Mean Squared Error (MSE) dan Mean Absolute Percent Error (MAPE) untuk menghitung kesalahan peramalan (forecast error).

\section{a. MAD-DES}

Langkah menghitung kesalahan peramalan DES periode ke-55 menggunakan perhitungan MAD yaitu sebagai berikut.

(1) Menghitung selisih antara nilai peramalan dengan data aktual tiap periode $\left|A_{t}-F_{t}\right|$

(2) Menjumlahkan selisih antara nilai peramalan dengan data aktual tiap periode $\sum\left|A_{t}-F_{t}\right|$, diperoleh nilai 19317.514602480005

(3) Jumlah selisih dibagi dengan jumlah data

$$
M A D=\frac{\sum\left|A_{t}-F_{t}\right|}{n}=19317.514602480005 / 54=357.73175189778
$$

\section{b. MSE-DES}

Langkah menghitung kesalahan peramalan DES periode ke-55 menggunakan perhitungan MSE yaitu sebagai berikut.

(1) Menghitung selisih antara hasil peramalan dengan data aktual tiap periode $\left|A_{t}-F_{t}\right|$ 
(2) Mengkuadratkan selisih antara nilai peramalan dengan data aktual tiap periode $\left|\left(A_{t}-F_{t}\right)^{2}\right|$

(3) Menjumlahkan hasil kuadrat dari selisih antara nilai peramalan dengan data aktual tiap periode $\Sigma\left|\left(A_{t}-F_{t}\right)^{2}\right|$, diperoleh nilai 10717201.381969403

(4) Jumlah selisih kuadrat dibagi dengan jumlah data $M S E=\frac{\sum\left|\left(A_{t}-F_{t}\right)^{2}\right|}{n}=10717201.381969403 / 54=357.73175189778$

\section{c. MAPE-DES}

Langkah menghitung kesalahan peramalan DES periode ke-55 menggunakan perhitungan MAPE yaitu sebagai berikut.

(1) Menghitung selisih antara hasil peramalan dengan data aktual tiap periode $\left|A_{t}-F_{t}\right|$

(2) Menghitung nilai APE tiap periode peramalan $\left(100-\left(\left(\left|A_{t}-F_{t}\right| / n\right) * 100\right)\right)$

(3) Menjumlahkan nilai APE seluruh periode peramalan $\left(\sum A P E\right)$, diperoleh nilai 347.2125018612248

(4) Menjumlahkan nilai APE seluruh periode peramalan dibagi jumlah data dengan perhitungan $M A P E=\sum A P E / n=347.2125018612248 / 54=$ 6.4298611455782

Semakin kecil nilai kesalahan peramalan, maka semakin akurat metode peramalan tersebut. Hasil perhitungan dari kedua metode peramalan dalam meramalkan penjualan produk jenang pada periode ke-55 menunjukkan bahwa metode Double Exponential Smoothing lebih akurat dibandingkan metode Trend Projection dengan MAPE atau persen nilai kesalahan metode DES yaitu $6.4298611455782 \%$ dan metode Trend yaitu $7.0837636367192 \%$, sedangkan persentase rata-rata keakuratan metode DES yaitu $93.570138854422 \%$ dan metode Trend yaitu $92.916236363281 \%$.

\section{SIMPULAN DAN SARAN}

\section{A. Simpulan}

Berdasarkan analisis dan pengujian yang dilakukan pada penelitian ini, maka dapat diambil kesimpulan sebagai berikut.

a. Aplikasi peramalan penjualan produk usaha kecil menengah berdasarkan pola data riwayat penjualan dapat dibuat dengan menerapkan dua metode peramalan yaitu metode Trend Projection dan Double Exponential Smoothing.

b. Pola data riwayat penjualan produk usaha kecil menengah dapat diketahui dengan melihat grafik data riwayat penjualan. Berdasarkan pola data riwayat penjualan produk pada UD Omah Jenang Kelapa Sari Blitar diketahui bahwa terdapat pola data musiman di mana setiap menjelang hari raya Idul Fitri dan menjelang hari raya Natal jumlah penjualan selalu meningkat. 
c. Hasil peramalan periode bulan berikutnya dapat diketahui dengan membandingkan persentase tingkat keakuratan dari kedua metode. Hasil perhitungan peramalan dari kedua metode pada periode ke-55 menunjukkan bahwa metode Double Exponential Smoothing lebih akurat dibandingkan metode Trend Projection dalam meramalkan penjualan produk jenang pada UD Omah Jenang Kelapa Sari Blitar dengan jenis pola data musiman. Persentase rata-rata keakuratan metode DES yaitu $93.570138854422 \%$ dan metode Trend yaitu $92.916236363281 \%$. Nilai peramalan penjualan produk jenang pada bulan Agustus 2017 metode Trend yaitu 6021.7922077922 dan metode DES yaitu 5988.39943011204. Hasil perhitungan kesalahan prediksi menunjukkan tingkat kesalahan metode Double Exponential Smoothing lebih kecil dibandingkan metode Trend Projection dalam meramalkan penjualan produk jenang pada UD Omah Jenang Kelapa Sari Blitar dengan persentase kesalahan metode Trend yaitu $7.0837636367192 \%$ dan persentase kesalahan metode DES yaitu $6.4298611455782 \%$.

\section{B. Saran}

Pembuatan aplikasi peramalan penjualan produk usaha kecil menengah berdasarkan pola data riwayat penjualan pada penelitian ini masih banyak terdapat kekurangan dan jauh dari kata sempurna. Untuk itu masih perlu dilakukan sebuah penyempurnaan. Berikut beberapa saran untuk pengembangan lebih lanjut dari aplikasi ini.

a. Menu dan fitur pada aplikasi ini masih dapat ditambahkan dengan menu yang lain bergantung dari kebutuhan sebuah perusahaan.

b. Dapat dikembangkan lagi dengan hak akses login multi user.

\section{Daftar Pustaka}

Brown, R. G. 1959. Statistical forecasting for inventory control. New York: McGraw-Hill.

Heizer, J \& Render, B. 2008. Principles Of Operations Management. New Jersey: Prentice Hall.

Margianti, E. dan Suryadi, D. 1995. Sistem Informasi Manajemen. Jakarta: Gunadarma. 